\title{
Dihak Ciptakan
}

\section{Semantics And Syntax}

Prof.DR.Drs.Seno H.Putra,M.Pd.

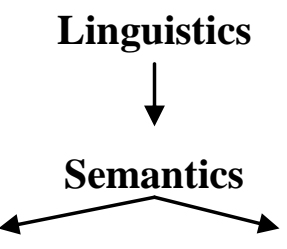

Science
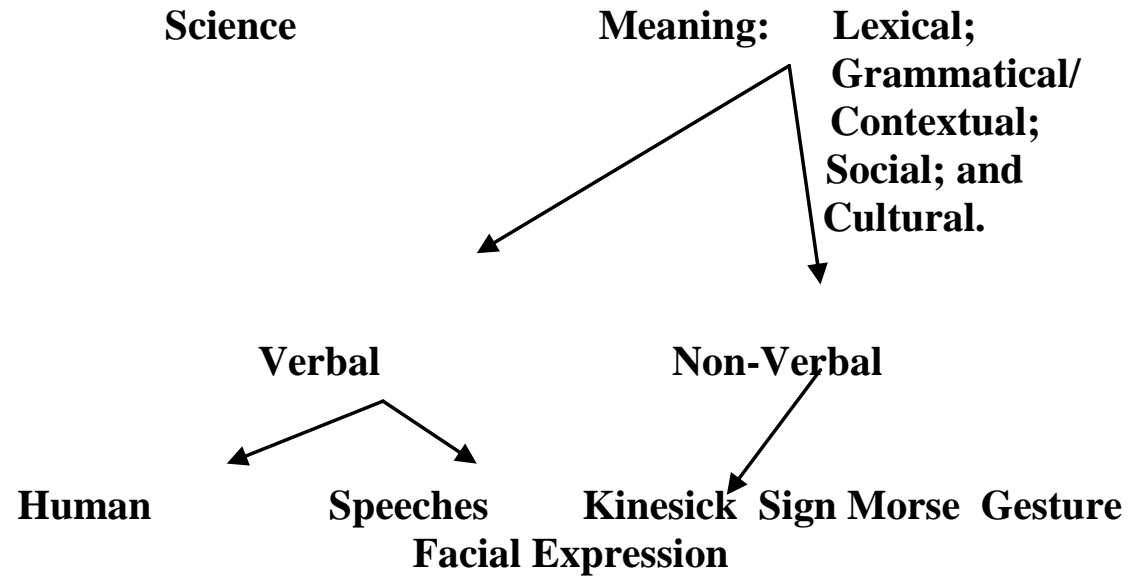

Even though Semantics is one of the branches of Linguistics, it has much important role in every language in the world whether spoken, written, or verbal and nor verbal skills. Semantics, moreover, is also a science that someone studies about not only the meanings of words, specifically, but also in sentences and clauses generally (Seno,20002004).

There are several terms of meanings in Semantics: There are (1) Lexical meaning; (2) Contextual Meaning/Grammatical Meaning; and (3) Social meaning/Cultural meaning. Seno (2004-2008) states that Lexical meanings, the meanings that refer to words in a real meaning as written in dictionary. In this case, words attached in dictionary explains the use of words and its varieties in a sentence generally, but if it considers that every word is used in the various fields of science, it certainly will be different meanings from one to another.For 
examples, Education word might not be used in Economics, Agriculture terms might not be used in Technics, etc.Therefore, someone must be careful in the use of each word whether in spoken or written forms.

Grammatical/Contextual meanings is the meanings indicate what meanings are in the sentence or clause in a language both surface and deep structures (Noam,1969). Furthermore, according to Seno (2006), grammatical/contextual meanings are not only focused on both terms, but it must also consider how the native speaker uses the sentences, as well as those sentences and clauses must be obeyed in the Native Speaker's system, rules, and its constructions. Other words, the sentences and clauses must be based on the system, rules, and its constructions of Native Speaker conventionally. This means that formal language, frozen, or standard of language based on the what, how, where the community uses that language formally.

Social and Cultural Meanings is the meanings refer to situation and condition of where the community uses the language. Besides that, geography also influences the processes of using language, especially in spoken form. However, in written form is usually more formal than spoken. For examples, in this case, in literary words, such as Novel, Proverbs, Poetry, poem, Drama, Film, Lyrics of songs, etc. Literary words can not only translated or predicted throughout one term of meaning, but all terms must be involved in those cases. Therefore, literary words need knowledge of the World of someone to comprehend the text of literary words (Seno,2008).

Dihakciptakan (CopyRight)

By Prof.DR.Drs.Seno H.Putra,M.Pd.

\section{God}




\title{
World/Objects/Fenomena
}

\author{
Various Species Human; \\ Animals; \\ Things; etc. Concrete Count Table Nouns \\ Abstract uncount
}

\section{Word Classes}

All species in the World are created by the God (Allah), the species that can be formed to be Nouns, like Human, Animals, Things, etc., referring to concrete and abstract ones, as well as countable and uncountable nouns, and also scientifically words can be categorized to be some classes, such as Noun Phrase, Verb Phrase, Adjective Phrase, Adverb Phrase, Preposition Phrase, Conjunction Phrase, etc.

Moreover, according to Word meanings, words can be divided into, for examples; (Lexical meaning); Grammatical/Contextual meaning; Social meaning; and Cultural meanings. Let us see Seno's Concept of Banana below.
a. Lexical > Entry Words in Dictionary
b. Grammatical/Contextual > Sentences/Clauses/Idea in a Paragraph
c. Social> Situation and Condition in a Certain Community (Country)
d. Cultural> Situation and Condition in Social, National, and Global Culture.

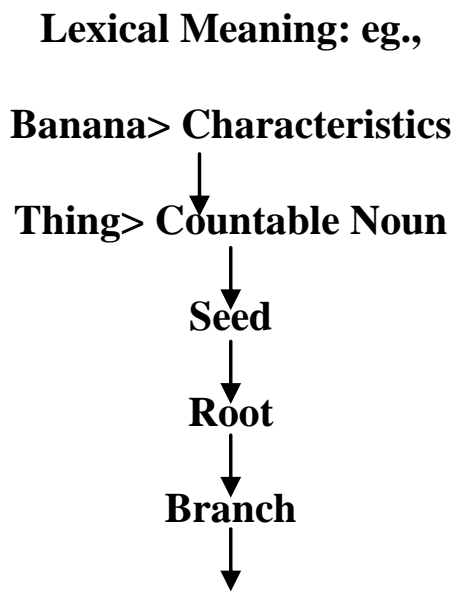




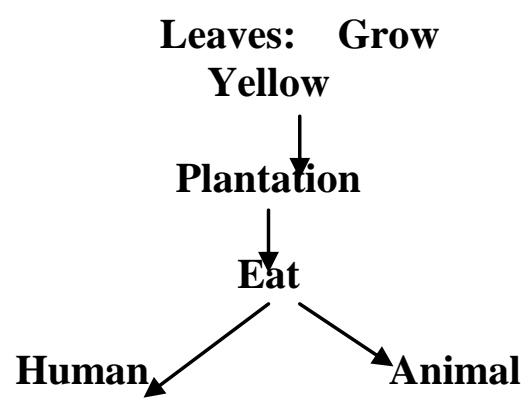

Based on the the sketch above, it can be explained that "Banana" has characteristics: (1) Thing; (2) Countable noun; (3) has seed; (4) Root; (5) Branch; (6) Leaves, like Yellow and later on to be Brown, it is also a kind of plantation, and that can be eaten by Human and Animal.

Find out the Characteristics of the following words.

$\begin{array}{lll}\text { (1) Salak } & \text { (2) Jengkol (3) Petai (4) Kedondong, etc. }\end{array}$

Dihakciptakan (CopyRight) By Prof.DR.Drs.Seno H.Putra,M.Pd.

(Seno's concept of Gramatical Meaning)

Grammatical Meaning> What the sentence is:

Atan reads Al-Qur'an: (NP+VP+NP1)



Related to the above Sentence, it is described that it is a simple Sentence that belongs to Present tense, done by Human as Atan, has activity of reading, the work of eyes, mouth, heart, and innate capacity to comprehend God's revelation. 


\section{Social/Cultural Meanings> Literary Words; Poetry; \\ Poem; \\ Lyrics of the Songs; \\ Drama/Sinetron/Filem; \\ Story Teller/Proverbs, etc.}

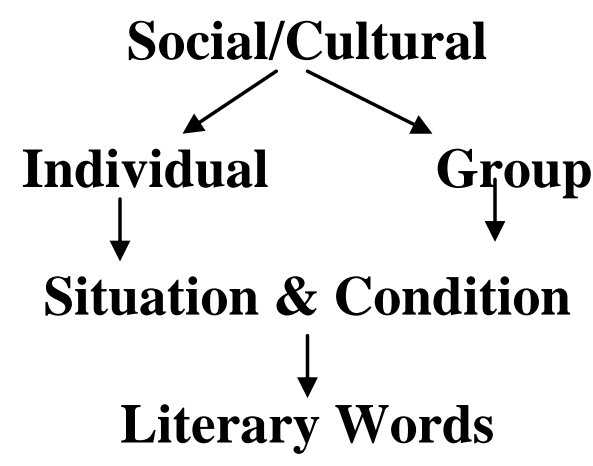

Based on the Diagram above, it is also detail explained that Lexical Meaning is the meaning derived from the Objects that can be explained through out the concepts (Opinions) of somebody scientifically, or based on the conventional. Those Objects (things) whether concrete or abstract, countable or uncountable ones are new must be named and detail and scientifically explained by those who are involved in the Language itself. Moreover, lexical meaning can also obtained from the Dictionary what the Language is (Seno,2011). However, He also states that Grammatical (Contextual Meanings) are the meanings derived from the words that later on these have particular meanings accordance with frozen or standard where the Language use.

According to Seno (2004), Social and Cultural meanings indicate to "Literary words" that can be found from someone's abstractness to be expressed through out whether spoken or written ones, such as Poetry, Poem, Lyrics of Songs, Proverbs, Scripts of Drama, Sinetron, Film,Novel, Story Teller., etc. Those derived from individual or a group of people depends on situation and condition, where the community uses the Language is.

Dihakciptakan (CopyRight) By Prof.DR.Drs.Seno H.Putra,M.Pd. 


\title{
Historical Naming of Objects
}

\author{
God > Asked Mention all the Things
}

Adam Prophet

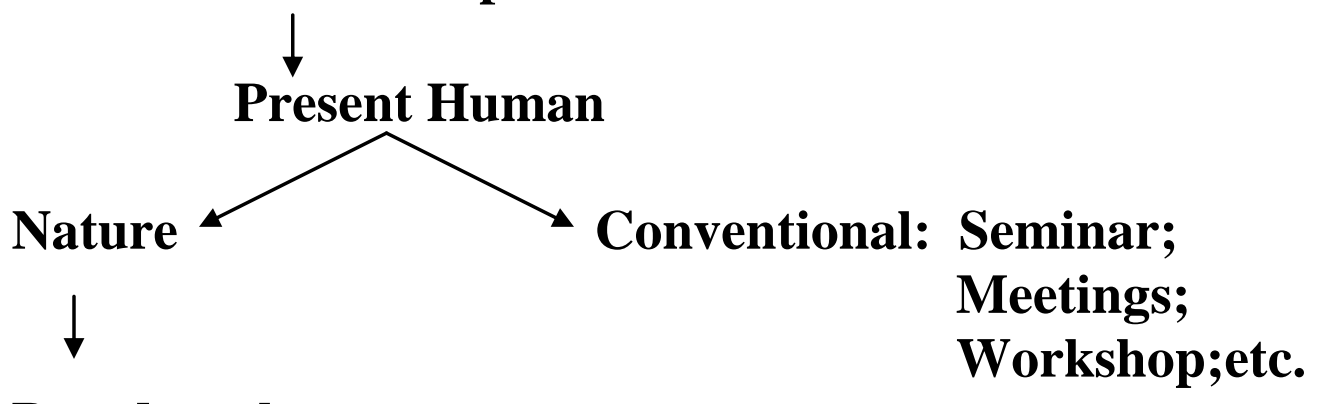

Based on the

Objects'Sounds Expert> Linguistics

$\downarrow \quad$ Community A

Paper > Cracker Cock, etc

Historical Naming of Objects derived from Nature' Sounds and Conventional, even those objects (Things), the Original Materials created by the God. But God asked Human to read think, and develop those in Education, Scientifics, and Science and Technology. To name the things focused on the nature, it is too limited rather than naming through Conventional, since in Conventional involves all Experts, particular Linguists done by Research or Scientifics, as well as socialized in Community followed and tested through Scientific meetings, like Seminar, Workshop, Panel Discussion, etc. 


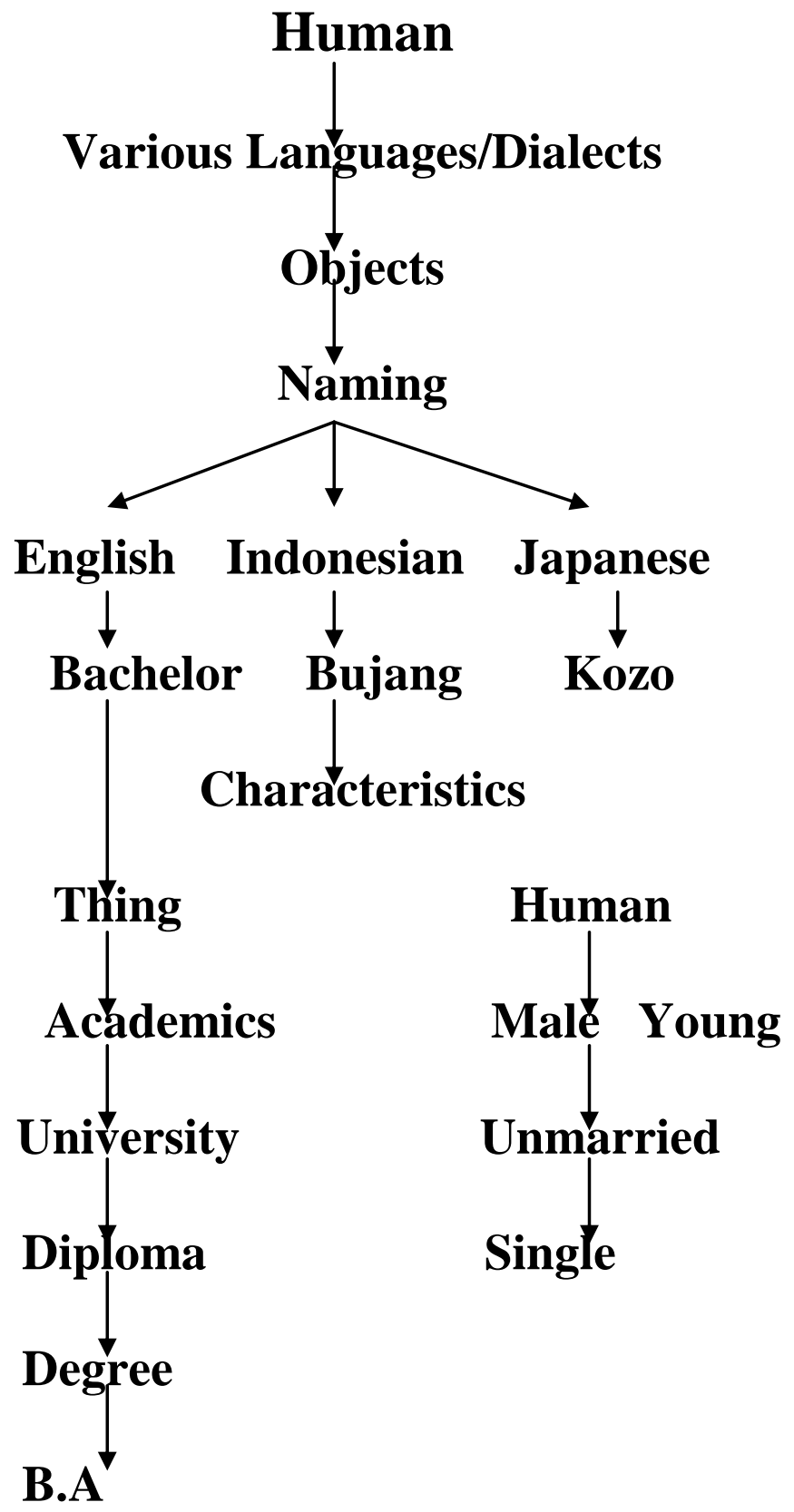

Students' Task

Find out make Examples with Various Languages that you know

By Prof.DR.Drs.Seno H.Putra,M.Pd.

Hakciptakan (Copyright) 


\section{Concepts of Words}

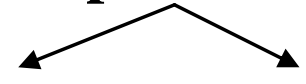

Thoughts References

$\downarrow$
Symbol Knowledge of the World

\section{Seno's Concepts of (Chair) \\ Wood, Metal, Iron, Plastics, Bambo, Rattan, dll. 4 Legs, 1 leg, etc. Arms, or Body Lying. Function: Sitted by human not Monkey.}

Words> refer to (Things). Various things have existed, or will exist in the world that can be seen and touched or not. Things can be named by community through out conventional and socialization to global community, and later on those can be habits and culture of society in expressing them, then they also become formal settings both spoken and written forms (Seno H.Putra, 2008).

Concepts, in my opinion, is not a draft of a piece of paper, but it is an idea of someone which refers experience, observation, reading, and including other references done by him/her previously or at present. Moreover, concepts are also derived from innate capacity, heart and soul of someone which can be expressed scientifically based on the objects (Things) naturally and creatively (Seno, 2009).

As my concepts and my hypothesis of "Chair" above, commonly if We ask "What is Chair"? So, everybody (Layman) often answers "Chair" only as "Sitting", but in Scientific and Academic Concepts, in my opinion, that Answer is not enough yet in such way, it must be detail explained according to "the Objects" so that those can not be ambiguous and confusing for somebody. Therefore, something is explained by Scholars 
is not similar to what "The Children or Others" answer, but Scholars at least must be answered based on the Philosophy of Science what he/she has.

Students'Task

Find out and Make examples based on your own knowledge of the World.

Hakciptakan by Prof.DR.Drs.Seno H.Putra,M.Pd.

(Copyright)

\section{Non Verbal Skills in Semantics}

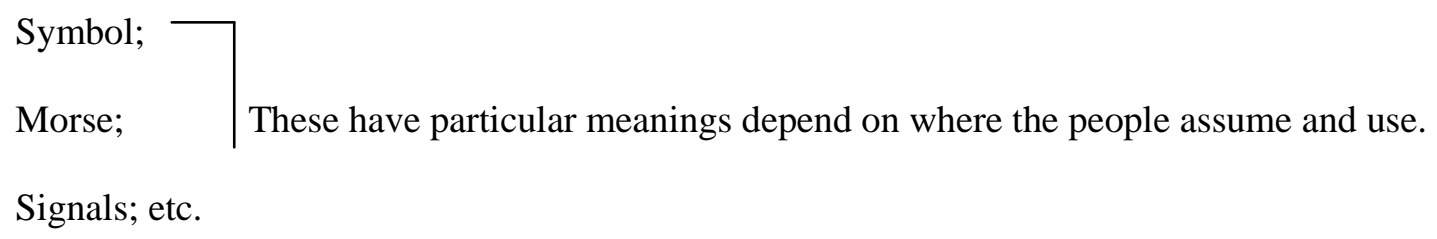

Fork and spoon $=$ Refers to..............

Red, Yellow, Green= Refers to

Many Children in the Alley $=$ Refers to

No Parking $=$ Refers to

No Smoking $=$ Refers to

Toilets $=$ refers to $\ldots \ldots \ldots$.

Analyze and think them over based on your own Assumption the following Pictures! 

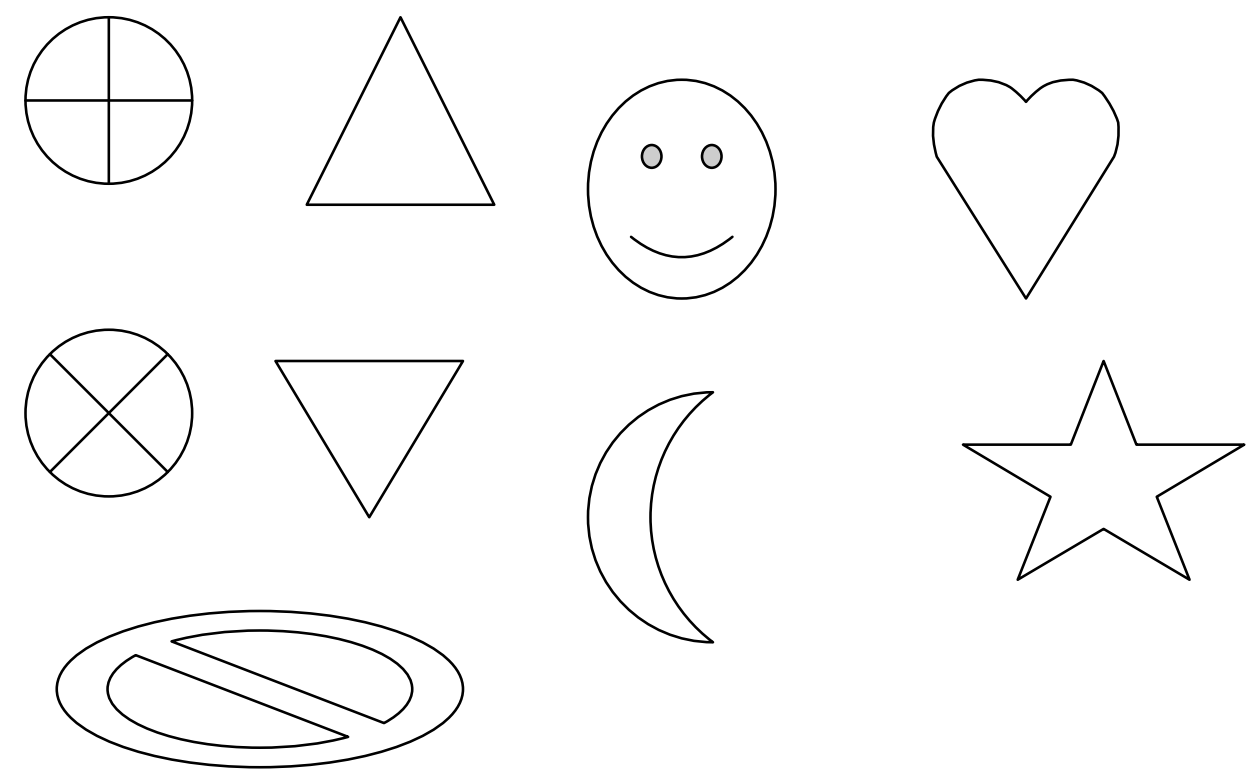

By Prof DR.Drs.Seno H.Putra, M.Pd.

Dihakciptakan (Copy Right)

White refers to the holy heart and soul and believe in God in the action and behaviour as Indonesian People and Nation in Doing all Aspects of Life.

\section{Reflection of Body to Language Behaviour}

This is also as a kind of Semantic field called as a Kinesick (Non-Verbal Skill). In an action done by human in expressing his ideas in speeches, he does not only use verbal skill, but he also uses his a part of his body internally and externally, so that what he wants to send messages to the other speakers are more optimally and perfect. Moreover, as normal Human to express something throughout vocal cords must involve some/whole his tools of his body, since if he does not use them, it is called as "Robot" (Seno,2004-2008). 
Therefore, My hypothesis states that "Verbal and non-Verbal Skills must be related to one another in human's speeches. Those, for examples, (eyes, arms, head, body, etc.) The movement of tools of body depend on "the Innate Capacity" both left and right brains. Left brain functions to keep all received data as mother board what to think, express, write, or to do something; while right one is to remind the left brain if he is forgetful at something (Long,1991;Seno,2005). In other words, right brain likes "black box" in the flight to record something if there is an emergency in it.

Language, furthermore, encompasses two devices in the use of application. One belongs to "Production" and "Reception". Production has two skills of human's speeches, that is (1) Speaking and (2) Writing. However, Reception belongs to (1) Listening and (2) Reading (Palmer, 1991 and Seno 2004). Read Seno’s Diagram below.

\begin{tabular}{|c|c|c|c|}
\hline \multirow{3}{*}{ Body Reflection } & & Production & Speaking \\
\hline & Language & & Writing \\
\hline & & Reception & $\begin{array}{l}\text { Listening } \\
\text { Reading }\end{array}$ \\
\hline
\end{tabular}

Eyes Arms Head Mouth Body, etc.

Movement Depend on Innate Capacity

By Prof DR.Drs.Seno H.Putra, M.Pd.

Dihakciptakan (Copy Right) 


\section{Semantics in Science and Technology}

As stated above, Linguistics also involves non-verbal skills, especially in Signals. Every signal is possessed by the Technology has its own particular meaning, which can be understood with reading, learning, practicing, or asking the experts who master it. The signals are attached (put) on/in the automotive or electronics are various meanings, for example, in the "Hand phone", someone can use it both spoken and written forms in a long distance communication between speaker and listener. For those who have more economics, they can only use "SMS" by pressing the letters are on that phone (Seno,2004). Hand phone, in addition to, also has other signals that can functioned not

only for send messages to others, but also for various uses, for examples, calculator, calender,etc., depends on the menu on that phone.

Computer, furthermore, also has signals and its soft programs. Its soft programs and signals have its own functions and meanings, so that when someone wants to operate it automatically the results of the pressing the signals can be seen on the its monitor. Therefore, Linguistics involves in Science and technology, in this case, particularly in Semantics.

Handphone; Computer;

Television;

Automotive;

Electronics;

Flight;

Calculator, etc. 
Semantics in Mathematics, Physics and Statistics

Eg., in Mathematics

$2 \times 3=\ldots . \quad 9-4=\ldots \ldots \quad 10 / 5=\ldots \ldots$. etc

By Prof DR.Drs.Seno H.Putra, M.Pd.

Dihakciptakan

TERMS IN SEMANTICS CONCERN WITH WORDS NAMING

SYNONYM= IS A WORD WHICH REFERS TO THE SAME MEANING AND

CHARACTERISTICS IN A THING THAT HAS BEEN CONVENTIONED BY WHERE THE COMMUNITY USE IT. SYNONYM, HOWEVER, CAN SOMETIMES BE DIFFERENT FROM PRONUNCIATION IN WORD. IN INDONESIAN IS USUALLY FOUND IN DIFFERENT DIALECTS USED BY DIFFERENT COMMUNITY (Seno H.Putra,2008).

E.g. $\quad K E L A P A=K A R A M B I H=K A L A P O=N I U R=N Y I U R=K E L A P E=K E L O P O, E T C$. , (CUCUNUT IN ENGLISH).

CUCUNUT IS THE SAME THING, CHARACTERISTICS, AND MEANING, BUT ITS DIFFERENT PRONOUNCED BY DIFFERENT COMMUNITY.

IN ENGLISH, TOILET, CLOSET (WC), ETC.

KAMAR MANDI=KAKUS=JAMBAN, ETC.

ANTONYM= is word which indicates the opposite of the mentioned word. The antonym has a lot of various forms of words not only in English, but also in other Languages, or dialects in the world. 
E.g. In English= Black $>$ White (Adj.P)

$$
\text { Quickly>Fast (Adv.P) }
$$

Find out $>$ Search for (VP)

Black board $>$ White board (NP).

Tinggi $>$ rendah (Adj.P) $>$ Indonesian

Worker $>$ Jobless (NP)

Employees $>$ Unemployees (NP)

Like>dislike (VP)

Rarely>often (Adv.P).

By Prof DR.Drs.Seno H.Putra, M.Pd.

Dihakciptakan (CopyRight) 
By Prof DR.Drs.Seno H.Putra, M.Pd.

Dihakciptakan (CopyRight)

\section{LITERATURE RESEARCH IN SEMANTICS}

Many kinds and forms of Literature have been created by various human in the World. Literature is a creativity of human through out imagination and knowledge of the world of speaker and writer which can be considered to become concrete and abstract, and each of which also has particular meaning (Seno,2008). According to experts of Literature, the kinds of literature can be divided into several forms, such as Poetry, Poem, Proverbs, Drama, story teller, Lyrics of Songs, Sinetron, film, etc.

Many problems (phenomena) of Literature in a Research, especially which can be related to Semantics. Those cases can be by the candidate Scholars of University or those who have involved in Academics. For examples, Many poetries and poems of both English and Indonesian written by various writers are sometimes difficult to understand, since the words, sentences, and language used in those kinds of Literature are not the same as common words used by the people. Therefore, for those are a part of Language Students, as well as Language Scholars, hopely are able to analyze them in a research, such as in writing scripts, or thesis.

As far as my experience be a lecturer, most of the candidate scholars of language have been seldom to conduct a research in Semantics. Most of the students, moreover, have been interviewed by the Writer in a few years at different Universities and Academies (1998-2008), they always response those kinds of research are difficult to do. 


\section{Discourse in Semantics}

Discourse is one of the other branches in Linguistics, and its function is to comprehend and analyze Sentences, Clauses, and texts of a Language. Discourse has been founded and sketched by Austin in (1962) as a science of Language Analysis from words and sentences to the largest one of language called as "Text".

No all words, sentences, and texts of a language can be interpreted and analyzed by every body as he likes, but those even though are not constructed in excellent forms according to native speaker, or not followed the rules and the systems of the standard one, those also have whether implicit or explicit meanings. Therefore, to have mutual understanding in the philosophy of a language, where someone is not enough to make out the standard sentences of a language, as well as the skills of a language, but they must have particular knowledge of the world, so that the discourses of a language can predict and assume to be become the real comprehension for both speaker and listener (Seno,17/Dec,2008). 
Dihakciptakan (CopyRight)

Syntax

By Prof.DR.Drs.Seno H.Putra,M.Pd.

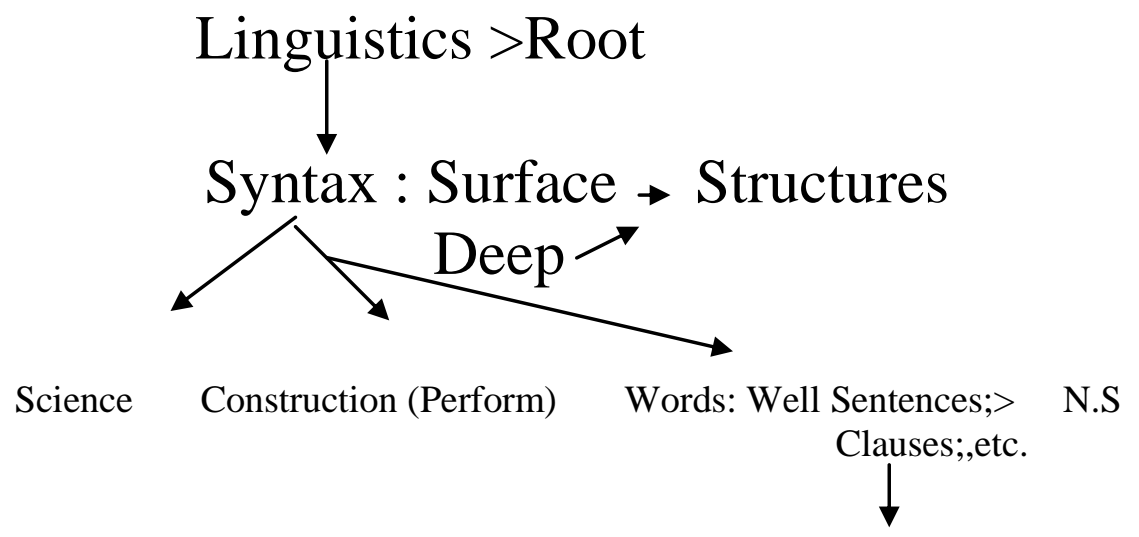

Rules \& Systems

\section{Grammar/Structure}

-Traditional;

-Predescriptive;

-Descriptive;

-Generative;

-Process of Innate, Vocal Cords, Mentality,Practice,Kinesick,and Environmental

Effect.(2005,Seno's Hypothesis).

One of the branches in Linguistics is "Syntax". Syntax is the science that we study about how to arrange or construct the words (phrases) of Language to be well Sentences and Clauses which are accepted by the Native Speaker. Syntax, moreover, also encompasses systems and rules of Language, and those must be constructed according to the frozen Language of English as conventional. Syntax, in this case, can be divided into two terms, that is; Surface and Deep Structures. In syntax, in addition to, to prove whether the Sentences and Clauses are well or not, those must be performed and analyzed do not only throughout Surface one, but also in Deep Structures (Seno,2001).

\section{Students' Task}

Perform the following words to be well Sentences! (Scramble Words) 
(a)

-Very>Adj.P

-Love $>\mathrm{VP}$

-Desy $>N P$

-Much>Adj.P

$-\mathrm{Sam}>\mathrm{NP} 1$

Dihakciptakan (CopyRight) By Prof.DR.Drs.Seno H.Putra,M.Pd.

(b)

-The>Art.

-Kick>VP

- Ball $>N P$

$-\mathrm{Cat}>\mathrm{NP}$

-The>Art.

WORDS LINK WITH OTHER WORDS IN SENTENCES AND CLAUSES
A. Word Classes: NP
VP
Adj.P
Adv.P
Conjunction Phrases
Prep.P
Art.

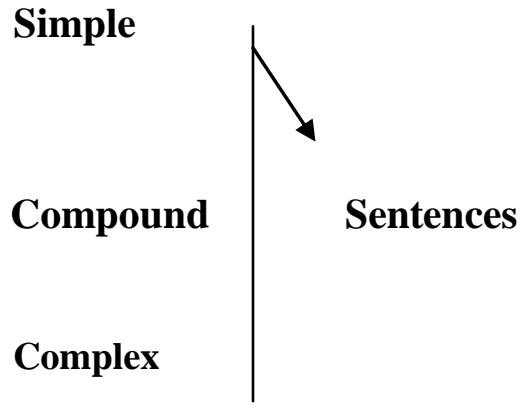

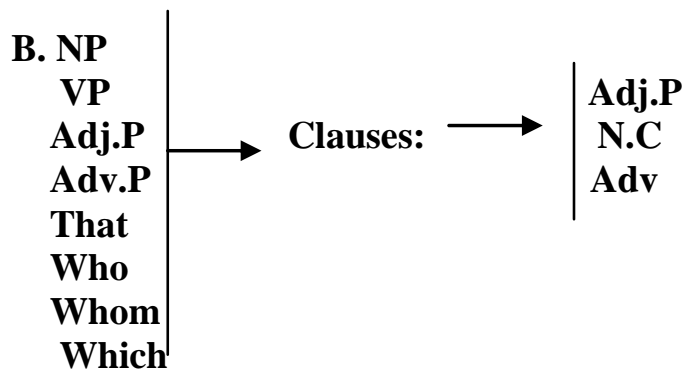


Words of every Language in the World always develop based on the human's civilization. Words, moreover, are the keys of each Language used by the community, where those are also tools to construct unlimited Sentences and Clauses both spoken and written forms (Seno,2004). Words, traditionally are called as "a part of speech", then development to be "Word Classes". According to classes, words are divided into several terms, for examples, Noun Phrase (NP); Verb Phrase (VP); Adjective Phrase (Adj.P); Adverb Phrase (Adv.P); Conjunction Phrase (Conj.P); Preposition Phrase (Prep,P); Article, etc. These phrases are tools to perform the unlimited Sentences whether in Simple, Complex, or Compound Sentences. Furthermore, these components of Language can also perform Clauses whether in adjective, noun, or adverb clauses.

By Prof DR.Drs.Seno H.Putra, M.Pd.

Dihakciptakan (CopyRight)

\section{Phrase Combines with other Phrases $($ Phrase + Phrase $)=(1$ M)}

\section{VP+ing+NP> Living Room}

2.NP+NP>Class Room

3.Adj.P+NP>Handsome Man

4.Adv.P+NP $>$ Slowly Driver

5.Part.P+NP $>$ Interested Person

\section{The Meaning of NP}

1. NP: Concrete

\section{Countable}

Abstract

Uncountable

Numbers

Nouns

Characteristics
Characteristics:

\author{
Some (+-) \\ Any (-) \\ A few (+) \\ Few(-) \\ Little (-) \\ A Little (+-) \\ Several (+), etc.
}


Noun Phrase is the phrase functions as an "actor or object" of the Sentence and Clause in a Language (English). Besides that, these noun Phrases can be Concrete, Abstract, Countable, Uncountable ones, etc. Noun phrases, in addition to, also consist of several components, that is Concrete, Abstract, Countable and Uncountable nouns, for examples, (1) Banana, Salak, Durian, etc., (C.N); (2) Hair, Sand, Sugar, Coffee, etc., (U.C); (3) Heart, Love, Sad, Happy, etc., (Abs.N) refers to internal appearance.

By Prof DR.Drs.Seno H.Putra, M.Pd.

Dihakciptakan (CopyRight)

2. >Transitive

$>$ Intransitive Verbs $>$ Function and its Characteristics $=$ An activity/Action Done by someone (Actor).

Verb Phrase is the phrase refers to an activity or action done by an actor in Sentences or Clauses of Language. Transitive verbs are the verbs can be followed by object (Other phrases), and these Verbs are unlimited in English. However, intransitive verbs are the phrases that can not be followed by objects, and these are limited in English.

E.g.

TV. Write $>$ Characteristics



Watch.....................................

IV.Find them by yourself.

3. Adj.Phrase: Internal> refers to inside character of things.

External $>$ refers to the performance of things. 
There are two kinds of adjective phrase in English, one belongs to inside character of things, for examples, (Sad, Friendly, Heart, Love, Happy, etc); and other belongs to external (performance) of things, such as (Beautiful, Handsome, Ugly, etc) (Seno,2008).

Inside character of things are something that can not be touched and seen by any body, except those can be seen and touched in the action or behavior of someone. External of things, however, are the adjective phrases that can be seen and touched by anybody, for example, (a beautiful lady, a handsome man, a white board, etc) (Seno,1992).

Find out and make examples of the following Adjective phrases internally and externally, including their own characteristics.

\section{Adv.Phrase> Refers to the volume (Quantity) of activities/actions done by Someone.}

\section{Adverb phrases are phrases which modify the volume (quantity) of activities/actions done by someone, for example:}
a. Atan drives a car slowly.
b. Andot cooks food quickly.

However, adverb phrases are also devided into several classes, such as (Place, time, conditions, etc). 
*Find out and make examples of the following Adjective phrases internally and externally, including their own characteristics.

By Prof DR.Drs.Seno H.Putra, M.Pd.

Dihakciptakan (CopyRight)

\section{Prep.Phrase> Refers to words that connect from one thing to another thing In a sentence or clauses.}

Preposition Phrases are the phrases which can link one thing to the another one in a sentence or clause of language. Besides, this phrase also encompass a few of terms called (common preposition, like at, on, in, under, beneath, above, for, etc.,); particles or verbs combine preposition, such as (look up, in, for, into, after, etc.,).

*Find out and make examples of the following Adjective phrases internally and externally, including their own characteristics.

\section{Article> Refers to things have been known previuously and also quantity (Number of things (a, an, and the).}

Article is used to indicate a number of human, animal, and things, like (a man, a han, an apple, etc.).But, article "The" is used for the thing has been known/mentioned before, for example, (The banana is on the table).

By Prof DR.Drs.Seno H.Putra, M.Pd.

Dihakciptakan (CopyRight) 


\section{A. Unit of Words Links with Others in Sentences based on the Constituency of Tree-Diagram and Boxes}

Ex. 1. Atan loves Ebot very much

a.

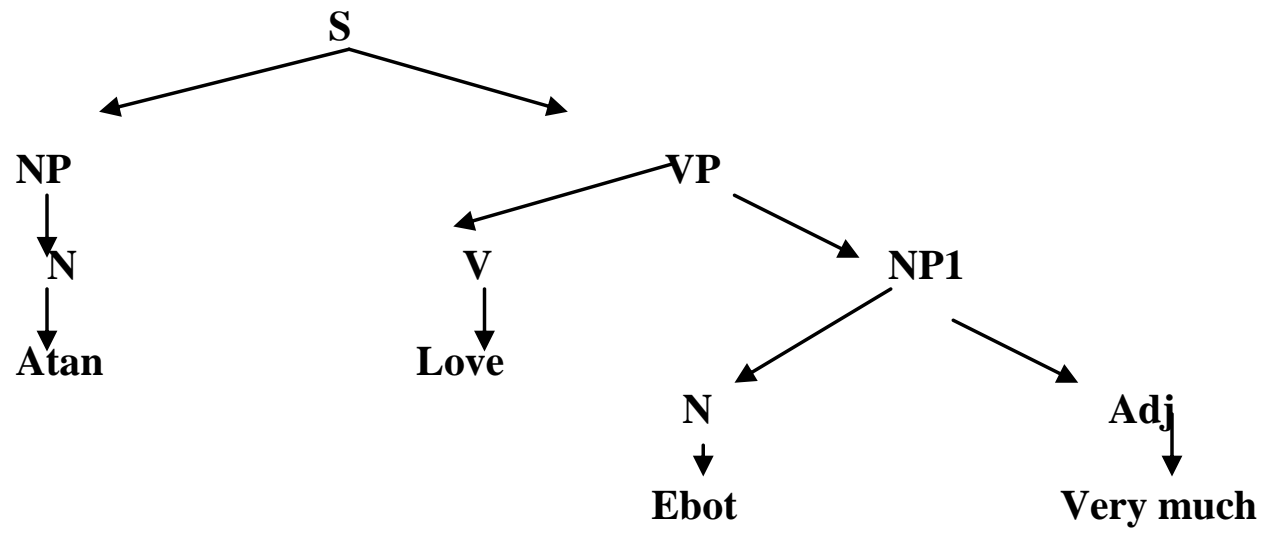

By Prof DR.Drs.Seno H.Putra, M.Pd.

Dihakciptakan (CopyRight)

b. 1. Atan loves > NP + VP

2. Atan loves Ebot $>\mathrm{NP}+\mathrm{VP}+\mathrm{NP1}$

3. Love Ebot $>$ VP+Np1

4. Love Ebot very much > VP+NP1+Adj.P

5. Love Ebot much > VP+NP1+Adj.P

6. Atan loves Ebot very much $>\mathrm{NP}+\mathrm{VP}+\mathrm{NP1}+\mathrm{Np2}$

Students'Task

*Analyze the following sentences whether these are kinds of sentences or not.

1. Open the door!

2. Close the door!

3. Sit down please!

4. Go out!

5. Come in please! 
6. Take a water please!

7. Go home!, etc.

Dihakciptakan (CopyRight) by Prof.DR.Drs.Seno H.Putra,M.Pd.

\section{Clauses}

Clause is the combination of sentences which refers to an actor acts something whether in Subject or Object. The clauses which modify the actor himself usually use (Who and Whom), besides that those can be (That, Which, etc). "Who" is used for person as a Subject, and "Whom" is for person as an Object. Moreover, "That" can be used for Person, Thing, and Animals; however, "Which" is only used for "Things and Animals".

E.g

a. Atan Who loves Ebot is my friend

Subject 1. Atan loves Ebot.

2. Atan is my friend.

3. Who loves Ebot?

4. My friend.

$1+3+2=6>$ S.C 
1.A tan Loves Ebot

2.Ebot Loves Atan.

Which one is correct?

\section{Boxes Formula}

1. Atan loves $>\mathrm{NP}+\mathrm{VP}$

2. Love Ebot $>\mathrm{VP}+\mathrm{NP1}$

3. Atan loves Ebot> NP+VP+Np1

Students" Task

*Analyze the following phrases based on the Tree-Diagram and Boxes Formula!

a. Atan loves Ebot very much is my friend

b. Analyze with Tree-Diagram, Boxes Formula, and Translation into Indonesian!

1. Atan loves Ebot.

2. Atan loved Ebot last year.

3. Atan will love Ebot next year.

4. Atan has loved Ebot recently.

5. Atan has been loving Ebot nowdays. 
6. Atan had loved Ebot when he was Senior High School.

7. Atan would have loved Ebot.

Dihakciptakan (CopyRight) by Prof.DR.Drs.Seno H.Putra,M.Pd.

b.Atan whom I met yesterday is my friend.
Object
1. I met Atan
2. Atan loves Ebot
3. Whom I met yesterday
4. Atan
5.When did I meet Atan?
6. Yesterday.

$3+1+2=6>0 . C$

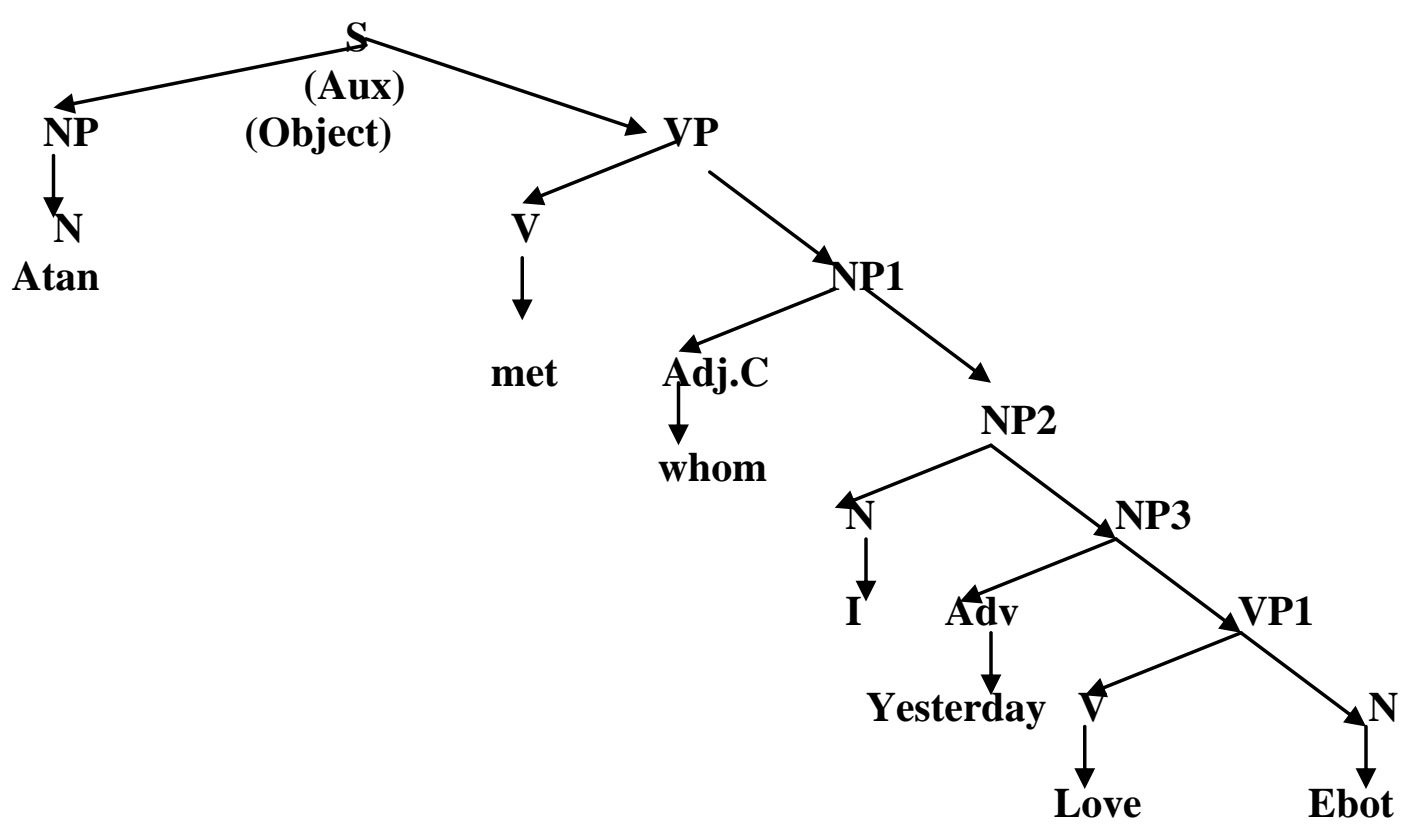

By Prof DR.Drs.Seno H.Putra, M.Pd.

Dihakciptakan (CopyRight) 
dihakciptakan (CopyRight) by Prof.DR.Drs.Seno H.Putra,M.Pd.

\section{SYNTAX IN SYSTEMS,RULES, AND STYLES}

Conventional > What and How does the Community use the Language formally?

Traditionally, according to some experts, things can be named according to their sounds, for example, (crackers, paper, cock, etc.), and these are only limitted to develop the words of language, because not all sounds are the same as mentioned things. However, conventionally, things are named based on the agreements of Linguists, and then those are socialized to global community where the Language use.

Even though Language was firstly created by the God as stated in the (Sentence of Albaqarah and Ar-rahman in Al-qur'an), the God asks us to use and the develop it according to human's civilization in the World. Words and styles of Language are always developed by human based on the community development, however, system and rules are very seldom one, since those have been frozen by the users.

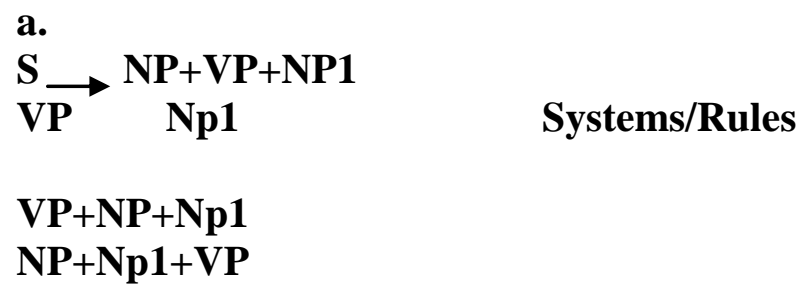

a. $\mathrm{S} \rightarrow \mathrm{NP}+\mathrm{VP}+\mathrm{NP} 1$

$\mathrm{VP} \quad \mathrm{Np1} \quad$ Systems/Rules

$\mathrm{VP}+\mathrm{NP}+\mathrm{Np} 1$

$\mathrm{NP}+\mathrm{Np} 1+\mathrm{VP}$

\section{b.Right to left (R-L) > (Arabics);}

Left to Right (L-R)> (Indonesian, English, etc.)

Top/Up to Down (T-D)> (Chinese, Japanese, etc.)

1. Dozoo go hang.

2. Saya makan nasi.

3. I eat rice.

Students' Task

- Find out and make examples based on the systems of various language that You know! 


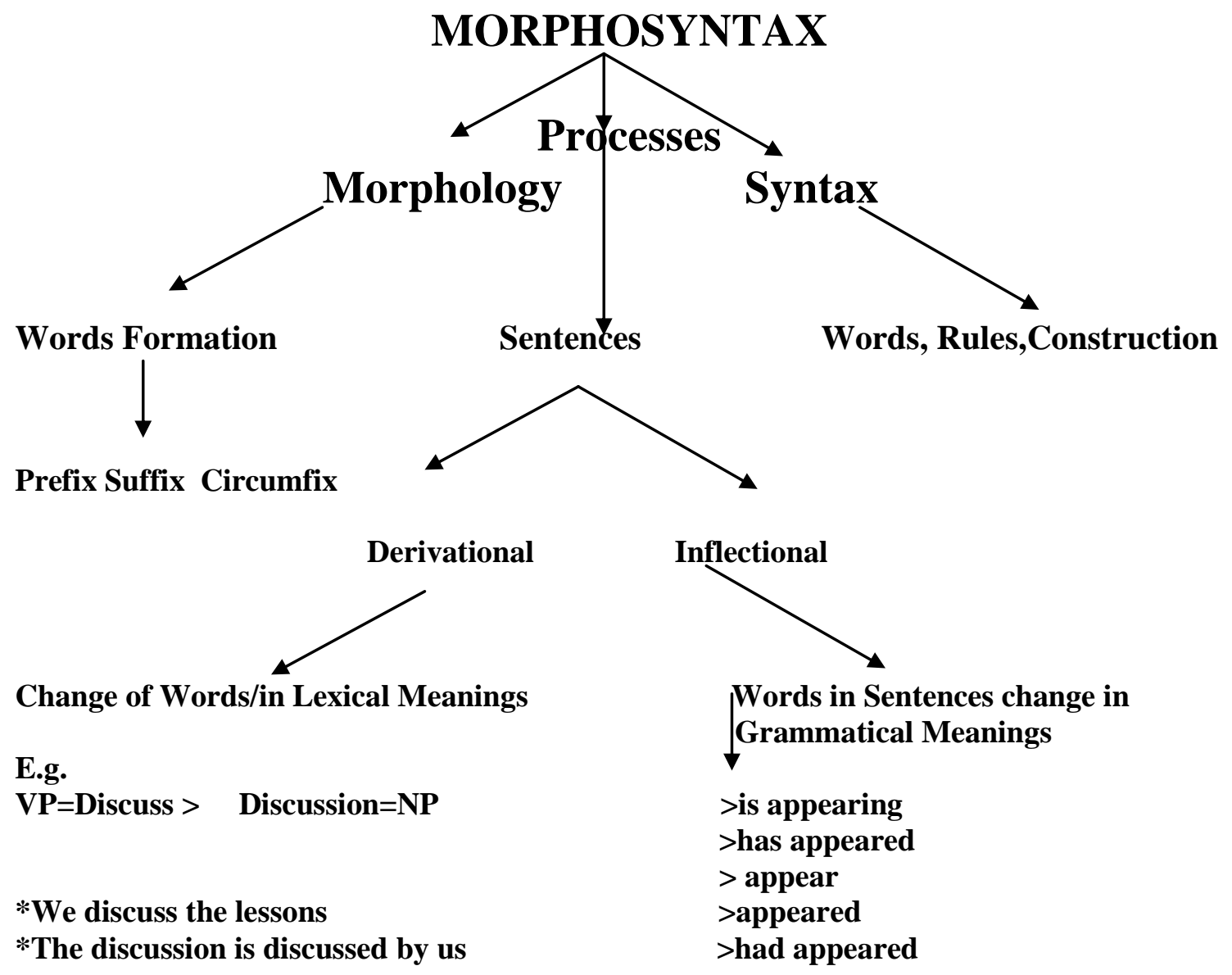

Morphosyntax is the combination of two fields of Science as the branch of Linguistics. Morphology is the Science that we study about how to perform words (Word-formation) derived from roots/stems of Language throughout the processes of affixations (Seno,1997). However, Syntax is the Science that We study what and how to construct words/phrases of Language to be well Sentences and Clauses accepted by Native Speaker (Seno,2001-2004). Therefore, in words formation of Language, both Sciences are needed to construct Sentences and Clauses, and the last those will be analyzed throughout field of Semantics. 


\section{Passive Sentences}

Passive Sentences (Voices) are kinds of Sentences in English. These Sentences are derived from Active Sentences, and the processes of changing the Verb Phrases and the positions of the actor depends on the times and tenses used in those ones, as well as what and how the actor acts something to the objects (NP). In addition to this, these Sentences must be followed by "Transitive Verbs", where the Verb Phrases which can be followed by the objects, or other Noun Phrases. The systems and the rules might be similar to Indonesian's ones, however, these Sentences can not be put "Intransitive Verb Phrases", since there are a few of English verbs can not be followed by objects (Seno,1992). Read the following examples.

1. Active: Atan proposes Ebot. Passive: Ebot is proposed by Atan

2. Active: Atan is proposing Ebot. Passive: Ebot is being proposed by Atan.

3. Active: Atan proposed Ebot last month. Passive: Ebot was proposed by Atan last moth.

4. Active: Atan has proposed Ebot recently. Passive: Ebot has been Proposed by Atan recently.

5. Active: Atan had proposed Ebot when Udin got married. Passive: Ebot had been proposed by Atan when Udin got married.

6. Active: Atan would have proposed Ebot. Passive:Ebot would have been proposed by Atan.

7. Active: Atan will propose Ebot next year. Passive: Ebot will be proposed by Atan next year.

Students' Task

*Perform the Boxes Formula and The patterns of each Sentence above. By Prof DR.Drs.Seno H.Putra, M.Pd.

Dihakciptakan (CopyRight)

\section{Task I}


Perform the following Words to become well Sentences accepted by Native Speaker of English!
A. 1. Bob
2. Nency
3. been
4. long
5. getting
6. $\mathbf{a}$
7. another
8. with 9.and 10. have 11. long time 12 . a
B. 1.Someone 2. up
3. stear
4. lady
5. beatiful
6. a

Task II

Perform the following Sentences to become Passive Voices of English!

1. Jane arrives at the Airport with his female friend.

2. Naufal visits Singapore.

3.The handsome man has thought something recently.

Task III

Perform these Simple Sentences to become Question Taq!

e.g., Rafif kicks the ball, _Doesn't he?

1. She never reads references much,--------------?

2. You sometimes study Structure with me,..................? 
By Prof.DR.Drs.Seno H.Putra, M.Pd.

\section{QUESTION TAG}

Question tag in English sometimes can be ambiguous if someone can not be careful in making these Sentences. In English, question tag encompasses two forms of Sentences, that is, if the main Sentence indicates "affirmative Sentence" (positive Sentence), the "Tag" must be in the negative one. Or if the main sentence modifies "negative Sentence", the "tag" might be in positive one. However, these constructions are not always done in such ways, those sometimes might change of constructions, for example, if the main Sentence looks like positive, but the content is negative, so, the "tag" must be positive. Besides, these "Tag" is usually put at the end of the Sentence depends on the auxiliary Verbs, Modals, Times and Tenses in the main Sentence. Therefore, the "question tag" of English are very unique, since a few of question tags can be ambigous for every body who never masters its constructions and its contents. Read the following examples.

\section{Students of English are studying Syntax, aren't they?}

2. Students of English are in the class now, aren't they?

From the above sentences, it is analyzed that the main sentences are different from one another in the use of "to be". "To be" in sentence (1) functions as helping Verb phrase in the Progressive Tense, but "To be" in Sentence (2) functions to refer the place, where the students are. Therefore, eventhough those sentences are not similar to the main ones, the "Tag' of which are the same construction.

\section{Students'task}

\section{Analyze and perform the following sentences in "Question Tag"!}

1. Atan never loves Ebot, ?

2. The Students of English rarely study Syntax, .......?

3. Everybody likes taking relax rather than working hard, ........?

4. Udin sometimes does the exercise,........?

5. There are many Salak on the refrigerator,.......?

6. Najeeh has a lot of books, ........?

7. Udin and Andot have got married for one year,.......? 


\section{Reciprocal}

Reciprocal is one of the English sentences which exist both spoken and written forms. Reciprocal is sentences which refer to take and give to the sentence itself (Seno,2004). In this case, Verb Phrases used in these Sentences are usually the repetitions what and how the actor acts. Thomson (1987) also states that reciprocal is the Sentence refers to "given and received" in return and mutual, or it expresses mutual action or relation from one to another. Read the following examples.

\section{Atan loves Ebot each other.}

This Sentence explains that not only Atan loves Ebot, but Ebot also loves Atan. The reciprocal in this Sentence indicates to the phrase of "Each other". In other words, both normal human beings take and give in "Love", and it is impossible done by one person without any reactions of others.

\section{The Students are still discussing in the class room.}

The Sentence number (2) explains that the Verb Phrase of "Discuss" usually modifies to the "the Action" of the reciprocal to the actors, where the Students talk to the other ones in discussions in the Class room.

*Find out, make examples, and analyze of Reciprocal ones based on your own sentences.

Dihakciptakan (CopyRight)

By Prof.DR.Drs.Seno H.Putra, M.Pd 
Dihakciptakan (CopyRight)

By Prof.DR.Drs.Seno H.Putra, M.Pd

\section{REFLEXIVE SENTENCE}

Reflexive Sentence is the Sentences which are used to emphasize pronoun is "oneself" (Swan,1988). In this case, it means that the Sentences which refer to an action or activity done by an actor himself. Many examples of English can be found in spoken or written forms, for example, (I myself do the exercises), etc.

Students' Task

Find out and make the examples of reflexive sentences with your own words. 
Denda Rp.100.000.000,- bagi Pembacak tanpa Izin Pengarang.

Dihakciptakan (CopyRight)

By Prof.DR.Drs.Seno H.Putra, M.Pd.

Undang-undang HakCipta N0.6 Tahun 1992; UU N0.7 Tahun 1987; dan UU N0.19 Tahun 2002

\title{
ENGLISH SYNTAX
}

\section{By Prof.DR.Drs. Seno H.Putra, M.Pd.}

\author{
(English Lecturer of the English Department of FKIP, \\ The Islamic University of Riau Pekanbaru)
}

\section{Bibliography}


Collins,J.T.1984.Shifting patterns of Language use in Borneo. Kuching: Borneo Research Council,Inc.

Chaika, Elaine.1982.Language the Social Mirror.Rowley:Newbury House Publisher.

Mathews,P.H.1992.Syntax.Cambridge:Cambridge University Press.

Frank, Marcella.1972.Modern English:A Practical reference guide.New Jersey:Prentice-Hall,Inc.

Chomsky,Noam.1966.Topics in the Theory of Generative Grammar.The Nederland:

Mouton\&Co.N.V,Publisher,The Haque.

Crystal, David.1975. What is Linguistics?. London: Edward Arnold.

Lass, Roger.1991. Phonology. Cambridge. Cambridge University Press.

Palmer.1991. Semantics. Cambridge: Cambridge University Press.

Putra, Seno.2000. Inroduction to General Linguistics. Pekanbaru:Cedes FKIP, UIR.

Putra, Seno.2006. Introduction to General Linguistics (Versi Revisi). Pekanbaru: UNRI Presss.

Putra, Seno.2004. Linguistik Hubungannya dengan Ilmu Pengetahuan dan Teknologi.Reset Riau.

Putra, Seno.1997-2006. The Morphology of Rengat Dialect in the Regency of Inhu, Riau Province.UIR

Press dan UNRI Press.

Putra, Seno.2004-2006. Morphosyntax of TM Dialect. Pekanbaru: Susqa Press.

Putra, Seno.2008.Alqur'an:Linguistics and Culture involve in Science and Technology. Reset Riau.

Putra, Seno.1992. A Practical English Grammar Mastery.Pekanbaru:UIR Press.

Putra, Seno.1998.Bahasa Melayu dan Penelitiannya (Makalah):Bulan Bahasa, Sasana Budaya, Pekanbaru.

Putra, Seno.2000.Beberapa Piranti dalam Sosiolinguistik. Pekanbaru:Jurnal FKIP,UIR.

Putra, Seno.1999.Analisis Wacana dalam Bahasa Media (Makalah):Bulan Bahasa.Pekanbaru.

Putra,Seno. 2002. Dialek dan Pandangan Masyarakat Melayu terhadap Bahasa Melayu.

(Seminar).Selangor:UKM, Malaysia.

Putra,Seno.2001.Dialek dan Melayu Purba. Makalah.(Seminar Internasional).Auditorium UIR.Pekanbaru.

Putra,Seno.2005.Draft Penelitian Qualitatif dan Quantitatif. Pekanbaru:Reset Riau.

Stork, F.C. 1974. Learning about Linguistics: An Introductory Workbook. London: William Clowes\&Sons Limited.

Denda Rp.100.000.000,- bagi Pembacak tanpa Izin Pengarang. 


\title{
ENGLISH SEMANTICS
}

\author{
By Prof.DR.Drs. Seno H.Putra, M.Pd.
}

(English Lecturer of the English Department of FKIP, The Islamic University of Riau Pekanbaru) 
